\title{
The ENVIRONMENT AND a GLOBALIZING SOCIOLOGY
}

\author{
RandolPh HaluZa-DeLay \\ DEBRA J. DAVIDSON
}

\begin{abstract}
The challenges for sociology posed by global environmental crises are two-fold. First, the growing prevalence of environmental dilemmas in global society demand that a globalizing sociology also be an environmental sociology. This requires the discipline to refine its ability to integrate environmental influences into its conceptual frameworks on social change. Second, the effectiveness of society's strategic responses to environmental crises depends on the degree to which understanding the generation of environmental problems and responding to them are sociologically informed. Consequently, sociologists can make important contributions to environmental improvement, through sociological research on environmental discourses within civil society. However, this can only be done if the first challenge is addressed.

In this paper, we highlight coupled socioecological systems functioning in an embedded hierarchy of local, regional, and global scales. Strategic environmental response depends particularly on governance structures and the production and accessibility of knowledge and we focus our discussion on these two domains. Global environmental changes have introduced multiple sources of challenge for nation-states and for the ways in which democratic participation in governance becomes operative. The dramatic shifts in governance fomented by environmental concern in and of themselves require sociological attention; sociologists also have a role in evaluating the efficacy of these organizational networks for addressing environmental crises. Second, we turn our attention to the means by which these environmental changes have challenged the production of knowledge about the environment. For example, the limits of traditional methods of scientific inquiry accompany an erosion in society's confidence in science as a harbinger of progress, all the while simultaneously pushing science - however reluctantly for scientists themselves - into a position of political prominence. We close with suggestions for future sociological attention to governance and knowledge, and the ways this projects sociology more effectively into the global milieu in which environmental change will be increasingly salient.
\end{abstract}

Résumé. Les défis que constitue la crise environnementale pour la sociologie présentent un double aspect. Tout d'abord, la prévalence des dilemmes environne- 
mentaux dans une société mondiale exige d'une sociologie mondialisante qu'elle soit également une sociologie environnementale. Cela exige donc que cette discipline soit davantage en mesure d'intégrer à ses cadres conceptuels les influences que peuvent avoir les changements environnementaux sur les changements sociaux. En second lieu, l'efficacité potentielle des interventions stratégiques d'une société en regard des crises environnementales dépend de la mesure dans laquelle la sociologie éclaire notre compréhension de la source des problèmes environnementaux et de la manière d'y réagir. Par conséquent, les sociologues sont en mesure d'apporter d'importantes contributions à l'amélioration de l'environnement, en amenant la recherche sociologique à s'appuyer sur les discours environnementaux qui ont cours dans la société civile. Toutefois, on ne peut y arriver que si l'on aborde le premier défi.

Dans cet article, nous mettons brièvement en lumière les moyens par lesquels les systèmes, social et écologique, sont mutuellement constitutifs, c'est-à-dire qu'ils sont des systèmes socio-écologiques associés qui fonctionnent dans une hiérarchie enchâssée d'échelles locale, régionale et mondiale. Ensuite, parce que la stratégie d'intervention environnementale dépendra en particulier des structures de gouvernance ainsi que de la production et de l'accessibilité des connaissances, nous analysons en détail ces deux domaines. Les changements environnementaux à l'échelle planétaires ont introduit de nombreux défis de tous types pour les nations-États et quant aux manières dont se met en œuvre la participation démocratique à la gouvernance. Deuxièmement, nous étudierons les moyens par lesquels les changements environnementaux mondiaux ont, dans le même ordre d'idées, remis en question la production de connaissances sur l'environnement. Par exemple, les limites des méthodes traditionnelles d'investigation scientifique sont mises à jour, en même temps qu'elles propulsent la science sur la scène politique. D'autres formes de connaissances agissent également comme des « contre-connaissances » envers la dominance épistémique de la science sur l'environnement. Nous terminons l'article par quelques suggestions quant à l'attention de nature sociologique qu'il faudra porter dans le futur à la gouvernance et à la connaissance, et par un examen de la façon dont cela projette la sociologie tout de bon dans le milieu planétaire dans lequel les changements environnementaux seront de plus en plus marquants.

\section{INTRODUCTION}

Then he picture of Earth taken from the Apollo spacecraft in 1969 has become iconic and powerfully representational: "This is our home, our common place," the photo seems to say, "beautiful yet fragile in the vastness of space." As Sachs (1994:170) expressed its impact, "The journey to the moon led to the discovery of the earth." Many argue that the photo of the earth became a symbol that galvanized awareness of both human global interrelatedness and ecological fragility. In the ensuing decades, 
attention to environmental matters has moved from localized to regional to global scales; from wildlife protection and urban pollution to earth summits and global treaties (Frank 1997; May 2005). The intensification of social impact on the biosphere has coincided with the intensification of global social and economic relations. While the latter have been subject to extensive scholarship across the social sciences, a primary premise of this paper is that an adequate account of our globalizing society cannot be provided without consideration of the biosphere.

Environmental matters have become such a prominent feature of $21 \mathrm{st}$ century social life that sociologists would be hard pressed to identify any empirical subject matter that has not been influenced in one way or another. The environment is a crucial element of global "North-South" tension, as evident in negotiations over post-Kyoto Protocol agreements. Global environmental change is integral to material social relations, the wellbeing of social and ecological systems, and to politics and culture. Failing to consider the means by which social and natural systems are mutually constitutive may limit the explanatory value of sociological inquiry. If prognostications are even partially accurate, the ramifications for society posed by environmental change will only grow in significance simply because the physical world is profoundly and abruptly changing. The environment is a vector of globalization; therefore, a globalizing sociology must attend more deliberately to the global environment in its sociological analyses.

The development of effective social responses to global environmental crises depends critically upon understanding the means by which human-induced environmental change is deeply embedded within global social, political, and economic relations and epistemic constructions. The success of efforts to address environmental problems is directly associated with the degree to which such efforts are sociologically informed; environmental problems are social problems (Bunker and Ciccantell 2005; Dunlap et al. 2002). Society depends on concrete sociological contributions to environmental discourse. This need is confirmed by recent discussions regarding public sociologies (e.g. Burawoy 2005; 2004; Blau and Iyall-Smith 2006). We agree with others that Burawoy's mandate to direct sociological research agendas toward particular audiences is problematic (McLaughlin and Turcotte 2007; Stacey 2004), and we are not suggesting that all sociologists must join the growing ranks of "activist scientists" currently engaged in environmental politics (Frickel 2004). However, the social ramifications of environmental crisis render acute the need to foster a discipline that is "responsive to public issues while at the same time committed to professional excellence" (Burawoy 2004:1616). Sociologists are well positioned to make substantive contri- 
butions to this area of study. The genius of sociology is its recognition of the dialectic of collective and individual processes that describe social systems, a methodology that can be applied to the complex interactions of societies and their environments.

The complexity of global social systems, characterized by interlinkages among multiple processes happening at different scales ranging from the household to the global economy, and the rapid and uncertain nature of changes within those systems, have themselves become defining features of globalization. Add to this social complexity the interaction between social activity and environmental change and we come to understand why interdisciplinary empirical research on "coupled human-environment systems" (Liu et al. 2007) is rare and usually regional in scale. The development of conceptual tools to handle the coincident forces of global social and ecological change is daunting. The harrowing complexity of our global social systems has rendered globalization a contested domain of social-scientific study. Globalization scholars who accept Robertson's (1992:8) definition of globalization as "both the compression of the world and the intensification of consciousness of the world as a whole," disagree about the degree to which economic integration is occurring, whether cultures are converging or diverging, and the extent to which globalization can be treated independently from modernization processes.

We make several modest suggestions at the end of this paper that we hope will simultaneously refine our disciplinary ability to contend with environmental change and provide opportunities for sociologists to make important contributions to environmental discourse. While environmental sociologists have been grappling with socioecological systems for at least 30 years, a recent assessment of the discipline of sociology by Lewis and Humphrey (2005) confirms the need for further appropriation by the discipline of the insights of this subdiscipline. Lewis and Humphrey conducted a content analysis of 24 of the internationally most used introductory sociology textbooks. Their data show that the environment is only addressed in a "social problems" format, and that key concepts from the subdiscipline of environmental sociology are not generally included in texts of broad introduction to the discipline. Lewis and Humphrey draw a parallel between current sociological treatments of environment-society interaction with early treatments of gender. Replacing a poorly integrated "add and stir" approach by the then androcentric mainstream with a reconceptualization that gender was integral to understanding human social interactions subsequently affected all areas of sociology. The development of the conceptual tools to handle the coincident forces of global social and ecological change will similar- 
ly advance a sociology better placed to maintain explanatory relevance for contemporary social systems.

We begin, in the next section, with a brief outline of sociological study understood as socioecological systems in which social and ecological components are mutually constitutive. Following this, we focus on sociological inquiry into two areas in particular - environmental governance and environmental knowledge. Governance is highlighted here, because our ability to address environmental crisis is dependent upon the vitality of governance networks to provide decision-making forums and policies to address socioecological concerns. We focus on knowledge because our very understanding of - much less the ability to attend to - environmental problems requires the rapid generation and dissemination of knowledge regarding social and ecological systems and their interaction, and the possible need for an adjusted knowledge domain.

Governance and knowledge are key to societies' abilities to contend with global environmental crises, but there are strong reasons to doubt whether this need can be met within the current structures of global governance and the academies that dominate the production of scientific knowledge. Environmental crises, and the growing public awareness of those crises, have introduced multiple sources of challenge for nationstates. Even with the growth of nongovernmental political organizations at local and international scales, the ability of the existing global governance networks to improve degraded environmental conditions is uncertain. Environmental crises have exposed certain fundamental limitations to traditional methods of scientific inquiry. They have eroded societal confidence in science as a harbinger of progress, while simultaneously pushing science into a position of political prominence. From this perspective, environmental failures are a vector for an epistemic recalibration of a genuinely globalized sociology.

\section{Grappling with the Socioecological System}

Two major scientific reports in recent years provide comprehensive and alarming assessments of the state of the world's environments, both in their proclamations about current and future environmental conditions, and the degree of consensus regarding those proclamations. The Millennium Ecosystem Assessment (Millenium Ecosystem Assessment [MA] 2005) and the Fourth Assessment Report of the Intergovernmental Panel on Climate Change (Intergovernmental Panel on Climate Change [IPCC] 2007) involved thousands of natural and social scientists from 
around the globe. The accumulated data show that humans have changed ecosystems more rapidly and extensively in the last 50 years than in any other period; approximately 60 percent of the world's regional ecosystems are now degraded or used unsustainably (MA 2005). Part of this ecosystem degradation can be attributed to human-caused global climate change, the effects of which are appearing faster than scientists had previously predicted (IPCC 2007). Anthropogenic climate change is predicted to have dramatic social effects - on communities, institutions, population dynamics, and social identities - that, while having locally distinct manifestations, will nonetheless reach beyond regional or national circumstances.

Production of all commodities and services requires drawing resources from the environment and the distribution of waste back into the environment. Society has always been associated with instances of environmental degradation, sometimes severe enough to engender regional socioecological collapse (Diamond 2005). Economic production is our primary material relationship to the environment, and the mechanism of most human-generated environmental problems, from species loss to climate change to toxic matter in the food chain. The exponential growth in economic production enabled by the spatial compression of the global marketplace, however, marks a distinct break from the past. The global expansion of the market economy has been founded on cheap energy and resource costs (MacKinnon 2007; Shelley 2005). The externalization of wastes - including greenhouse gases - has overwhelmed the absorptive capacity of the environment, suggesting that environmental disruption has the potential to undermine the global economy.

The global dimensions of environmental do not imply that the social effects are equal, however. Global environmental changes introduce an additional source of global inequalityto an already grossly unequal global economic system (Roberts and Parks 2007). While more places are pulled into production for the world economic system, the manifestation of local environmental consequences are as unequal as the rates of material production and consumption, highlighting the fragmentation, unevenness, and discontinuity associated with global expansion (Smith 1984; Sutcliffe 2000). Global environmental problems assume distinctly regional manifestations, with some areas facing severe consequences and others largely unaffected. A paradoxical recursivity results, as locales are affected by but also affect other scales - the interactional and multidirectional processes of "glocalisation" (Robertson 1995).

Even localized environmental hazards can be associated with global social feedback mechanisms. The economic and social costs of regional environmental degradation can have ripple effects throughout the tightly 
integrated economic relations characterizing the global economy. For example, the decline of particular fisheries shifts extraction elsewhere with the results that fishery stocks globally are inadequate to meet current population requirements (MA 2005). Environmental change continues to be associated with altering global power geometries and population restructuring, although we may ascribe such changes to "globalization," "geopolitics," or "energy security," rather than "the environment" (Escobar 2001; Smith 1984). The economic relations defining the current global economy should be seen as malleable and historically contingent, subject to abrupt changes in environmental as well as social conditions. However, because poorer countries need economic growth to achieve adequate living conditions, the inequality between underdeveloped and overdeveloped countries is a profound environmental problem for a globalizing sociology.

Although the expertise to construct the global circulation models that are central to climate science is beyond the grasp of all but a few, basic understanding of our environmental quandary is not difficult. Simply put, increases in population and material consumption are supported by increased use of resources - either nonrenewable resources like fossil fuels or so-called renewable resources like fisheries and fertile soil. Those material and energy resources easiest to access and convert to human use are consumed first. Over time the maintenance of the same consumption levels - never mind increasing levels - requires ever more effort to extract and process those resources (Frickel and Freudenburg 1996; Schnaiberg 1980). Given that both the production and consumption of many of those resources generate waste in the form of ecological degradation and environmental contaminants, global economic development is currently based on the rapid depletion of key natural resources from increasingly remote regions of the globe. Ecological footprint analysis - an impact measure using the metaphor of the land and productive sea necessary to produce or dispose of the materials and energy used for human consumption (Wackernagel and Rees 1996) shows that current economic activity is equivalent to 133 percent of the earth's capacity (Global Footprint Network 2006.).

Of course social systems have not been passive in the face of environmental change. The fact that effective mechanisms are still wanting for many environmental concerns does not diminish our tremendous capacity for social learning (Homer-Dixon 2001). The tandem processes of globalizing society and the globalization of environmental crises, however, have generated dilemmas sufficiently complex that our collective capacity to address them has not evolved fast enough. Greater sociological attention to socioecological systems will not only provide much- 
needed sociological knowledge to the task of environmental improvement, it will also aid in the disciplinary task of improving and globalizing sociology in the service of a compressed and intensified world.

\section{The Governance GaP}

\section{Current Sociological Understanding of States}

Environmental crisis challenges many of the current premises of governance. While environmental governance involves several organizational actors beyond the nation-state, which will be discussed further below, it presently depends upon the authority and institutional capacity that nation-states have historically provided. We consequently begin our discussion of environmental governance with current work on state theory. Work by Evans, Reuschmeyer, and Skocpol (1985) provides a useful 3 part ideal-type with which empirical variations in state activity have been evaluated:

1. nation-states are defined as the highest authority within a defined geographic territory with the right to resort to the use of force;

2 . the primary purposes of which are to maintain internal order, military competitiveness, and economic development;

3. whose effectiveness is enabled by the autonomy to make decisions in the state interest, and the capacity to implement those decisions.

That few states are perfect empirical expressions of this ideal-type does not change the utility of the model. Rather, the degree to which states express this ideal-type provides an appropriate metric of state strength and stability.

This ideal-type has been the premise for many recent discussions of the potential decline in salience of the nation-state in a globalized society, with a literature far too extensive to review here (e.g., Holton 1998; Kozlarek 2001; Sassen 1996; 1998). The very autonomy and capacity of states described above, based on state sovereignty in the international sphere, has been whittled away by the exponential growth in the number of international agreements, trans-national corporations, and extragovernmental agencies that currently describe the global polity (Sassen 1996).

One primary means by which nation-states have attempted to manage the growing complexity associated with this global system has been the establishment of strategic networks with organized factions of private and civil society (Evans 1995; see also Migdal 2001). Environmental nongovernmental organizations are adept at entering these networks, representing one of the most active transnational social movements (della 
Porta et al. 2006). This state-society synergy, or embedded autonomy, is now so prominent that sociologists, political scientists, and others refer to political decision-making in the context of governance, to capture the multiple nonstate actors now engaged in the political process.

The environment both instils and challenges many conceptual features of governance described above. The emergence of global environmental problems, ironically, represents one realm of political decisionmaking in which the salience of the nation-state perseveres. Organizational responsibility for the protection of "common pool resources" - air, water, fisheries, and biological diversity are some examples - remains formally with nation-states (Frickel and Davidson 2004). This does not guarantee effective state management. Environmental problems, global and otherwise, pose fundamental challenges to nation-states, including the need for international cooperation; the potential contradictions posed by nation-state responsibility for both environment and economy; and effects on citizenship and democracy. Each of these is discussed briefly below, raising opportunities for further sociological discussion.

\section{Governing the Global Commons}

The decided disrespect for political boundaries on the part of ozone, wildlife, water, climate, and other features of the global commons, poses a particular problem for the geographical integrity of states. Recognition of the porous nature of national boundaries is nothing new - migratory bird treaties between Canada and the United States date back nearly 100 years. One could argue that international agreements regarding common pool resources and cross-border pollution, in which only nation-states can function as signatories, confirm the sovereign status of the nationstate. On the other hand, the recognition of global environmental problems such as climate change, biological diversity loss, and ozone depletion have challenged the contemporary system of state sovereignty by demanding the assumption of state responsibility in instances in which national interests and costs are quite divergent (see, e.g., Fisher 2004). States are called upon to exhibit characteristics for which most are poorly suited, including accountability for past actions that have contributed to contemporary environmental problems, responsibility for future victims of the environmental costs of current actions, and global welfare, or willingness to compromise national economic development for the betterment of the global whole.

Manoeuvres in the past decade regarding the 1997 Kyoto Protocol illustrate clearly the limitations of a sovereign state system for addressing complex global environmental problems. Kyoto was convened as the 
first step of a global strategy to address climate change. Post-Kyoto negotiations have been plagued by state manoeuvres owing to wide variations in national economic wellbeing, and, more importantly, variations in the extent to which that wellbeing is dependent upon the emission of greenhouse gases. ${ }^{1}$ Much of this debate centred on two states that were not signatories to Kyoto, but were to be brought into the next stage China and India. Representing a full third of the global population, even steadfast commitment of these countries to ecological modernization would not eliminate a marked increase in their emission of greenhouse gases in their efforts to reach Western standards of material development. Negotiators from developed countries (particularly those for which compliance with Kyoto targets would demand significant changes to national economies, such as Canada, Australia, and the United States), argued against stiff reductions unless India and China faced the same targets. China, India, and other countries not in the initial Kyoto Protocol, on the other hand, could rightfully point out that the current concentration of greenhouse gases in the atmosphere was almost entirely due to past activity from developed countries and they have every right to improve living standards for their citizens through the same industrial paths to economic development that were so fabulously successful for Western Europe and North America (Makarenko 2007; Roberts and Parks 2007). In a woeful twist of the dialogue, negotiations regarding the most significant environmental crisis of the modern era were thus transformed from one of responsibility for pollution, to one of right to pollute.

The ascendancy of any given state has always been contingent upon control over access to natural resources (Bunker and Ciccantell 2005). However, the effort to control ownership over ecological "sources" those key natural resources necessary to human survival and social development - contrasts sharply with state effort to deny ownership of the ecological "sinks" responsible for the absorption into land, water, and air of societally produced wastes.

Such efforts to negotiate international environmental standards have not only fallen short of their goals, they have in some cases exacerbated international tensions through an all too familiar North-South divide, in which the advanced industrial states of the northern hemisphere have asserted control over the conditions of debate, a power structure reinforced through global financial institutions. Many developing countries in the southern hemisphere have consequently been subject to a form of en-

1. Meeting emission targets in Canada, for example, a large, cold country with heavy reliance on industries and energy sources associated with high greenhouse gas emissions, represents a substantial feat in comparison to a country like Germany, whose economy depends far less on greenhouse gas emissions. 
vironmental "colonialism," as official bodies like the World Bank impose environmental management stipulations on loan recipients, demanding the commitment of scarce domestic resources to an environmental agenda defined by northern states, rather than to urgent social welfare needs (Chase-Dunn and Babones 2006; Goldman 2001).

\section{Contradictory State Roles: Economic Growth and Environmental Wellbeing}

Environmental wellbeing has an equally tenuous position on the domestic priority list of most nation-states. In both domestic and foreign policy, state hesitancy to assume responsibility for environmental improvement can be explained partly in terms of historically defined state roles. Because state interests can usually be explained by the pursuit of one of the three primary roles of states described by Evans, Reuschmeyer, and Skocpol (1985), we might anticipate that states would only take substantive responsibility for environmental wellbeing when environmental dilemmas impinge on one or more of these primary roles (Frickel and Davidson 2004). In many instances, however, the assumption of environmental responsibility is viewed as a direct contradiction to one of the state's primary roles - the ability to foster economic growth. States consequently avoid substantive environmental protection, opting instead for symbolic measures designed to appease an environmentally concerned civil society, until the prospect of catastrophic ecological collapse threatens the treadmill of economic production itself (Foster 2002).

The pre-eminence of economic wellbeing for state legitimacy has been exacerbated by the penetration of the global market into every domestic economy across the globe. Much environmental management consists of trade-offs: depletion of natural resources in exchange for short-term employment, destruction of an ecosystem at one site in exchange for the creation of protected areas elsewhere (e.g. Davidson and Hatt 2005). Faith in such substitutions is a core premise of a currency-based economy, whereby the "goods" marketed in today's global economy include everything from waste, insurance against environmental disaster (two of the largest global industries today), and tradable pollution permits. Ultimately, states are both complicit in further environmental destruction (Foster 2002; Schnaiberg 1980) and a hindrance to innovative environmental protection (Carr 2004; MacKendrick and Davidson 2007).

\section{Democracy, Citizenship, and the Environment}

Considering that environmental impacts and natural resource depletion are in most instances irreversible - even in the case of "renewable" 
resource collapse - environmental crisis may lead to a legitimacy crisis for the nation-state after all (Barry and Eckersley 2005; Frickel and Davidson 2004). The potential for civil society to foment such a legitimacy crisis, however, and the nature of society-based environmental political uprisings in general, is defined by the precarious relationships between environmental wellbeing, citizenship, and democracy. A central tenet of the sociological study of democracy is that equality is axiomatic (Dahl 1989) and that participation of citizens, under equal terms, decides the appropriate political course of their society (Saward 1994). Yet environmental degradation poses a challenge to the pursuit of citizenship and democracy alike. While citizenship rights and democratic structures are defined nationally, environmental amenities are not. So while political identities are formally defined via the nation-state, an individual citizen may bear a more fundamental relationship with other individuals who share the same ecological territory, but not the same political territory. Drawing water from or emptying pollutants into a cross-boundary waterway, for example, is engaging in a material relationship with other peoples in the watershed, impinging upon the abilities of those others to also make use of that waterway. Similar to the growing instances of ethnic nationalism across the globe, which often has a territorial or spatial dimension (Holton 1998), these material relationships have such political importance that some political thinkers are considering the primacy of watershed or bioregion citizenship over nationhood; localization in response to global environmental crisis (Carr 2004; Lipschutz 1996).

The material relationship between those benefiting from environmental disruption and those assuming the costs is not always so vivid. Owing to the complex spatial and temporal paths of interaction among ecosystem components, environmental degradation is often not tied to place of origin or means of production. Global temperature increase, for example, is greater in northern latitudes where ecosystems are less resilient. The Arctic is not a site of carbon emissions, but it faces a disproportionate share of the ecosystemic effects, and their impacts on social wellbeing and cultural practice, bringing formerly remote populations like the circumpolar Inuit onto the international political stage (Watt-Cloutier 2004). Similarly, 15 percent of Bangladesh is expected be underwater from an anticipated one-meter rise in sea level over the next century, displacing at least 15 million persons from that country alone (IPCC 2007). Therefore, another direction for ecological citizenship in response to global environmental degradation is that of "earth citizen" or cosmopolitan ecological citizenship (McGregor 2006; Urry 2000). Consistent with the glocalization thesis, Thomashow (2003) argues for the fruitfulness of "cosmopolitan bioregionalism." The point is that the pre-eminence of 
nationhood in forming citizenship identity can be superseded by other identifications in response to globalizing environmental awareness.

Lastly, socioecological interaction inevitably involves nonhumans, which further upsets the system of citizen participation and democratic representation. The democratic system is based on a progressive historical project of extending citizenship to more and more humans (nonpropertied, women, freed slaves, racialized others, etc.), but only humans to this point. Although democratic participation is the means by which decision-making is meant to be made equitable, the "otherthan-human" have no present participation unless others speak for them (Brosnan 2006; Nash 1989; Stone 1974). Some environmental theorists and activists extend moral valuation and even forms of agency to "earth others" (Plumwood 2002:56), which calls modernist ontologies of citizenship into question and points to them as historical constructs (Merchant 1980; Taylor 2004). Lindemann (2005) carefully argues the need for sociologists to consider anew the "borders" of the social world that delimit who or what is considered a social actor. Bhambra (2007) asserts that sociology is particularly immune to challenges to its boundary work over the constitution of "the social," which is comparable to the challenges ecological citizenship theorists are providing to existing democratic theory and practice by asking how other-than-human concerns can be brought into the democratic process (e.g., McGregor 2006; Plumwood 2002; Smith 2001; Urry 2000).

Environmental scholars have provided considerable evidence that differential exposure to environmental harms is a function of socioeconomic inequalities, rendering environmental risk a central feature of contemporary national and global stratification (Agyeman, Bullard, and Evans 2002; Roberts and Parks 2007). The imposition of environmental risk onto others could be considered ethically reprehensible even under equitable circumstances (Dobson 1996). Yet because virtually all social manipulations of the environment involve such costs, states are left with the unpleasant job of distributing the social and ecological costs of environmental impact. This poses critical challenges to democratic decision-making under the best circumstances. The effects of global transborder and even transcitizen environmental circumstances requires reconsideration of environmental governance.

\section{The Knowledge GaP}

According to Beck's (1992 [1986]) articulation of the risk society, most of the environmental risks of modern life escape perception, and are in- 
stead "observed" through the methods and instrumentation employed by Western science. Consequently, as the complexity of environmental dilemmas grows, so too does the dominance of scientific expertise, and the differential access to the knowledge products of science. The tendency to devise technocratic solutions to environmental problems has the effect of removing decision-making power from citizens or their elected representatives even in strong democracies, creating a societal dependency on scientific expertise for information on the nature of social and environmental risk (Jasanoff 1990).

On the other hand, studies of the social production of knowledge have burgeoned since Kuhn's initial work on scientific paradigms demonstrated science as a socially contingent product. Much recent research focuses on the contentious public dissemination of scientific information (e.g., Irwin and Wynne 1996), and its politicization (e.g., Freudenburg 2005; Song and McGonigle 2001; Stehr 2001). These efforts have inevitably led researchers into the environmental realm. Perhaps more than any other area of scientific enterprise, environmental dilemmas have been held responsible for fundamentally changing society's relationship to science, and fomenting a critique of Western epistemology itself (e.g., Bowers and Apffel-Marglin 2005; Braun and Castree 1998; Harding 2006; Merchant 1980; Plumwood 2002). Sociology's contribution to social strategies for environmental improvement, however, will require better understanding of the challenges associated with knowledge production in the environmental sciences, and the complex processes of knowledge uptake and feedback in global society. Below, we briefly describe several means by which environmental dilemmas have become a source of contention for the academy and its relation to society.

\section{Environmental Challenges to Scientific Institutions}

Science plays a central role in environmental politics because of its paradoxical position as the source of many of our environmental dilemmas, and the source of awareness of, and solutions to, those environmental dilemmas. Environmentalists are plagued by this paradox: they critique the role of science and technology in creating multiple human-caused environmental hazards, while, at the same time, relying on science to enhance the credibility of their claims. This paradox has not been lost on the broader public in Western societies either. The emergence of environmental issues on the political stage has been credited with the rapid downfall of science's long-established position on the pedestal of Western culture and rationality (e.g., Irwin and Wynne 1996). The routine marginalization of citizen concerns as "anecdotal evidence" in environ- 
mental disputes has only added fuel to the fire - science is not only held up as the cause of environmental hazards; scientists themselves are frequently accused of bias. As a result, public debates often ensue about everything from genetically modified foods to hazardous waste storage, climate change, and Hurricane Katrina. Such debates bring into sharp relief the socially and politically situated nature of scientific production, and place society in a rather tenuous position - science is facing a significant crisis in public trust, yet we are more dependent upon science than ever to identify and address environmental ills.

Ultimately, debates ensue over where and how to allocate epistemic authority in a society (Gieryn 1999). Community responses to localized environmental disasters, and local traditional knowledges about environmental change, are "counterknowledges" contesting the pre-eminence of Western science, and posing a reappropriation of the knowledge domain (Featherstone and Venn 2006; Goonatilake 2006; Kozlarek 2001). Cultural knowledge, after all, is the mechanism by which we interact with our environment, including our social and biophysical environments (Milton 1996). Globalization brings with it the awareness that not all societies construct knowledge the same way. To assert by fiat that such differences represent poorer understandings of the world, or that (Western) sociology has a truer understanding of culture as above nature is to reassert the project of colonialism (Appadurai 2001; Smith, 1999). That Environment Canada has allowed Aboriginal traditional ecological knowledge (TEK) to be taken into account in decision-making is just one example of the growing legitimacy of other knowledge claims (Berkes 1999). A globalizing sociology, challenged by worldviews that are not Western, must account for these ontological and epistemological differences, which, taken seriously, challenge the received view of Western social science.

Within the academy itself, environmental degradation brings to the surface once-latent weaknesses within Baconian science based on Enlightenment philosophy of technomanagerial control. Traditional scientific rationality's principled reliance on the objectivity of the observer is a manifestation of the underlying ideology of anthropocentrism that many fault for the creation and perpetuation of environmental crises themselves (Demerritt 1998; Plumwood 2002). As we address environmental problems, the tendency of the scientific academy to reduce complex systems to individual components for observation has been found wanting. Indeed, one could argue this tendency is reflected in the structure of the academy itself, being compartmentalized into specialized disciplines in a manner that reduces complex reality into atomistic parts. 
Ecologists have been forced to abandon traditional scientific methods of observation, opting instead for systems approaches to accommodate the enormous complexity of interlinkages among multiple climatic, hydrological, geological, and population dynamics. Ecology, in its situated and nonreductionist focus, is itself a counterknowledge, even within the physical sciences (Roth and Bowen 2001). A globalizing sociology can learn from the experience of those doing international development work around the world (Munck and O'Hearn 1999). Increasing ecological side effects of conventional development paradigms raise doubts about their validity in structuring knowledge production and application in this field. Describing this as "doubts about [the] destination and validity of the map" Sutcliffe (2000) explains the ways the scholarship and practice of international development is deciding how the environment is to be taken into account - within a basically unchanged but slightly more complicated framework, or in a thoroughgoing move away from the "modernization" paradigm that was the prescriptive solution to problems of the so-called third world. The latter response corresponds to both methodological and epistemological shifts in development work, requires attending to indigenous knowledge, and leads to acknowledgement of limits of human knowing and technical ability to overcome ecological limits, precisely the effects we project for sociology. It is recognition of the complexity of coupled socioecological systems.

\section{An Agenda for Sociology}

As a premise for advancing the discipline and developing sociologically informed contributions to civil society's dialogue on environmental improvement, sociology should direct its conceptual and empirical energies in a number of strategic directions, beginning with a deeper theoretical integration of global socioecological intersection. Such a task is not without challenges which would give pause to the most capable of complexity theorists. Environmental crisis imposes a range of social costs that manifest themselves differentially, amid a complex system of economic, political, epistemological, and ecological processes. Environmental justice scholars, world systems theorists, and political ecologists have provided several important components of this puzzle. One challenge for sociology is to integrate heretofore independent avenues of inquiry, including processes of global economic stratification, the global distribution of environmental hazards, the global differentiation in the power to participate in environmental decision-making, and the paradigms under which socioecological interaction is perceived. 
If instances of environmental degradation can emerge as a legitimacy crisis for states, or as a source of justification for the expansion of those states (Frickel and Davidson 2004), then increased attention to how environmental conditions manifest themselves in political conflict is also warranted. An astute observer of geopolitical events in recent decades could point to a number of instances in which conflicts have been associated with environmental conditions and natural resource supply; just as relevant for sociological analysis are those cases in which extreme cases of environmental degradation fail to arouse a political response among its victims. How states respond to environmental degradation, and how effective are those responses, have also been the subject of much research in political science and environmental sociology. These efforts could be advanced by sociologists situating empirical events within the broader context of state theory, to develop a conceptual framework describing the limits and potentialities of environmental state-making at the local, nation-state, and international level.

While we have a reasonably well-developed conceptual understanding and empirical record for nation-state activity, the rise to prominence of international environmental organizations, both governmental and nongovernmental, has been phenomenal (Frank, Hironaka, and Schofer 2000). Globalization has enabled supranational cooperation via environmental treaty-making, and the development of transnational environmental governance regimes (Frank 1997; Kanie and Haas 2004). In some nations, international environmental nongovernmental organizations have largely assumed responsibility for environmental governance, with a stronger presence in environmental decision-making than the nationstate itself. This organizational growth has far outpaced the ability of sociologists to accommodate it in conceptual models of governance and state-making.

Local-level organizational responses to environmental degradation often fall under the rubric of NIMBY, or Not In My Back Yard movements. Such efforts in isolation often simply relocate, rather than reduce, environmental pollution. More recent research indicates an impressive degree of networking and a growing coherence among localized responses to environmental risk, for example, an environmental justice movement network that is increasingly global in scope, aided by the emergence of transnational organizational networks (Agyeman, Bullard, and Evans 2002; Caniglia 2001; Keck and Sikkink 1998). Local organizational responsiveness to prototypical global environmental problems has been compelling, compared to nation-states. For example, despite the official stance taken by the US government on Kyoto, over 400 American city mayors across the United States have pledged their support as part of 
the Mayors' Climate Protection Agreement (http://www.usmayors.org/ climateprotection), and several states have passed Kyoto-inspired legislation. In other realms, political ecologists have illustrated the manipulation of land and resource management by a complex mix of local and nonlocal, state and nonstate actors (e.g. Peet and Watts 2004). Research into local environmental politics, however, is all-too-often conducted in isolation, limiting the potential benefits to the broader discipline that could be provided by knowledge accumulation.

Ultimately, what remains to be conceptualized satisfactorily are the relations among these differing organizational scales, that is, the dialectic of "glocalization," with environment as a vector. A more lucid understanding of the multiscalar interactional effects of social systems will enable sociologists to locate synergies and constraints associated with particular socioecological configurations within each system.

The evolution in Western society's relation to science and its contentious role in environmental politics are described in the social studies of science literature as summarized above. Sociology can map the changing dynamics between knowledge and global society, and include greater attention to alternative knowledges. Important to this undertaking will be an account of the (re)emergence of forms of knowledge production other than Western science (Carolan 2005; Matsinthe 2007; Pulido 1998; Featherstone and Venn 2006; Smith 1999). Globalization has intensified awareness of the plurality of human cultures, their diverse and contrasting models of human environmental relations, and the range of ways that societies understand their environment, all of which undermine claims to universality by Western knowledge providers (Appadurai 2001). Many alternative knowledge forms already accommodate one of the key challenges to Western scientific methods: system complexity. Escobar (2001:151) writes that for many indigenous peoples, for example, "living, non-living, and often times supernatural beings are not seen as constituting distinct and separate domains - certainly not two opposed spheres of nature and culture - and social relations are seen as encompassing more than humans." To the extent that Western, anthropocentric rationality is a root cause of ecological degradation, intercultural interaction in the production of environmental knowledge is also beneficial to environmental improvement

Sociology's relevance to environmental improvement also demands disciplinary self-reflexivity. The "conceptual armoury of existing social science categories" is inadequate to both a globalizing and an environmentalizing sociology (Featherstone and Venn 2006:10). Greater attention to environmental phenomena will improve sociological treatment of social categories such as knowledge, the state, citizenship, cultural 
consumption, and so on. In addition, sociology must come to theoretical terms with the ecological embeddedness of social systems. Three decades ago, Catton and Dunlap (1978) charged sociology with a tendency to exclude nonsocial phenomena from analysis, which they termed the "human exemptionalist paradigm." Since that time, the field of environmental sociology has become a well-developed subdiscipline. There is also growing interest in the environment among mainstream sociologists (Dunlap et al. 2002). Similar to their ecologist contemporaries, practitioners of environmental sociology conceptualize social systems as embedded within ecological systems and include environmental processes in their research, which we argue would be beneficial to all sociology. They have developed a number of conceptual innovations to address the "interactionality of society-nature" (Carolan 2005; Goldman and Schurman 2000; Murphy 2004). Such innovations in sociological theory have been seen as radical, because they challenge modernist principles to "recogniz[e] nature as an active participant in the production of self, society and our ethical values" (Smith 2001:212). Further advancement of such conceptual efforts, and their eventual influence on other sociological research, however, demands better cross-fertilization within sociology, and deeper linkages with other disciplines. More fluid and open engagements within and among the social sciences are the most productive means of mapping the dynamic and conjoined character of the socioecological systems of the 21st century (White 2006).

Sociology's position as a modern social science is characterized by Western worldviews, which is particularly problematic for its globalizing (Bhambra 2007). As McDaniel (2003) observes, sociology tells itself even as it purports to describe the social world. It is thoroughly Westernized even as it presumes universality. A globalized sociology - forced by global environmental phenomena to notice the ecological dimensions of social systems - can aid resistance to the global spread of Westernstyle modernity with its attendant ecological consequences. A globalized sociology would acknowledge the limits of human knowing and technical ability to overcome ecological limits. Adjusting sociology's conceptual apparatus to account for ecological processes is a step toward improved explanatory power. This sort of globalizing calls attention to other knowledges that share the planet with Western social scientific paradigms: counterknowledges which heretofore represented "silenced social spaces" in contemporary environmental discourse (McKechnie and Welsh 2002). A globalized sociology attentive to the environment can improve our understanding of human social life, thus better accounting for social formations and change across human societies. 


\section{REFERENCES}

Agyeman, Julian, Robert B. Bullard, and Bob Evans, eds. 2002. Just Sustainabilities: Development in an Unequal world. London: Earthscan/MIT Press.

Appadurai, Arjun. 2001. Grassroots globalization and the research imagination. Pp. 1-21 in Arjun Appadurai, ed., Globalization. Durham, NC: Duke University Press.

Barry, John and Robyn Eckersley, eds. 2005. The State and the Global Ecological Crisis. Cambridge, MA: The MIT Press.

Beck, Ulrich. 1992 [1986]. Risk Society: Towards a New Modernity. London: Sage Publications.

Berkes, Fikret. 1999. Sacred Ecology: Traditional Ecological Knowledge and Resource Management. Philadelphia, PA: Taylor \& Francis.

Bhambra, Gurminder K. 2007. Rethinking Modernity: Postcolonialism and the Sociological Imagination. Basingstoke: Palgrave MacMillan.

Blau, Judith and Keri E. Iyall-Smith, eds. 2006. Public Sociologies Reader. Lanham, MD: Rowman \& Littlefield.

Bowers, C.A., and Frederique Apffel-Marglin, eds. 2005. Rethinking Freire: Globalization and the Environmental Crisis. Mahwah, NJ: Lawrence Erlbaum Associates.

Braun, Bruce, and Noel Castree, eds. 1998. Remaking Reality: Nature at the Millennium. New York: Routledge.

Brosnan, Sarah F. 2006. Nonhuman species' reactions to inequity and their implications for fairness. Social Justice Research 19(2):153-85.

Bunker, Stephen G. and Paul S. Ciccantell. 2005. Globalization and the Race for Resources. Baltimore: Johns Hopkins.

Burawoy, Michael. 2005. For public sociology. American Sociological Review 70(1):4-28.

2004. Public sociologies: Contradictions, dilemmas and possibilities. Social Forces 82(4):1603-1618.

Caniglia, Beth S. 2001. Informal alliances vs. institutional ties: The effects of elite alliances on environmental TSMO networks. Mobilization 6:37-54.

Carolan, Michael. 2005. Realism without reductionism: Toward an ecologically embedded sociology. Human Ecology Review 12(1):1-20.

Carr, Mike. 2004. Bioregionalism and Civil Society: Democratic Challenges to Corporate Globalism. Vancouver: UBC Press.

Catton, William R. and Riley E. Dunlap. 1978. Paradigms, theories and the primacy of the HEP-NEP distinction. The American Sociologist 13:25659. 
Chase-Dunn, Christopher and Salvatore J. Babones, eds. 2006. Global Social Change. Baltimore: Johns Hopkins University Press.

Dahl, Robert A. 1989. Democracy and its Critics. New Haven, CT: Yale University Press.

Davidson, Debra J. and Kierstin Hatt. 2005. Consuming Sustainability: Critical Social Analyses of Ecological Change. Halifax: Fernwood Press.

della Porta, Donatella, Massimiliano Andretta, Lorenzo Mosca, and Herbert Reiter. 2006. Globalization from Below: Transnational Activists and Protest Networks. Minneapolis: University of Minnesota Press.

Demeritt, David. 1998. Science, social constructivism and nature. Pp. 173-93 in Bruce Braun and Noel Castree, eds., Remaking Reality: Nature at the Millennium. New York: Routledge.

Diamond, Jared. 2005. Collapse: How Societies Choose to Fail or Succeed. New York: Viking

Dobson, Andrew. 1996. Democratising green theory: Preconditions and principles. Pp 132-148 in Brian Doherty and Marius de Geus, eds., Democracy and Green Political Thought: Sustainability, Rights, and Citizenship. London: Routledge.

Dunlap, Riley E., Frederich E. Buttel, Peter Dickens, and A. Gijswijt, eds. 2002. Sociological Theory and the Environment: Classical Foundations, Contemporary Insights. New York: Rowman and Littlefield.

Escobar, Arturo. 2001. Culture sits in places: Reflections on globalism and subaltern strategies of localization. Political Geography 20:139-74.

Evans, Peter. 1995. Embedded Autonomy: States and Industrial Transformation. Princeton, NJ: Princeton University Press.

Evans, Peter, Deitrich Reuschmeyer, and Theda Skocpol. 1985. Bringing the State Back In. London: Cambridge University Press.

Featherstone, Mike and Couze Venn. 2006. Problematizing global knowledge and the new encyclopaedia project: An introduction. Theory, Culture \& Society 23(2-3):1-20.

Fisher, Dana R. 2004. National Governance and the Global Climate Change Regime. New York: Rowman and Littlefield.

Foster, John B. 2002. Ecology against Capitalism. New York: Monthly Review Press.

Frank, David John. 1997. Science, nature and the globalization of the environment, 1870-1990. Social Forces 76:409-435.

Frank, D.J., A. Hironaka, and E. Schofer. 2000. The nation-state and the natural environment over the twentieth century. American Sociological Review 65(February):96-116. 
Freudenburg, William R. 2005. Seeding science, courting conclusions: Reexamining the intersection of science, corporate cash, and the law. Sociological Forum 20(1):3-33.

Frickel, Scott. 2004. Scientist activism in environmental justice conflicts: An argument for synergy. Society and Natural Resources 17(3):359-366.

Frickel, Scott, and Debra J. Davidson. 2004. Building environmental states: Legitimacy and rationalization in sustainability governance. International Sociology 19(1):89-110.

Frickel, Scott and William R. Freudenburg. 1996. Mining the past: Historical context and the changing implications of natural resource extraction. Social Problems 43(4):444-466.

Gieryn, Thomas F. 1999. Cultural Boundaries of Science: Credibility on the Line. Chicago: University of Chicago Press.

Global Footprint Network. 2006. Ecological Footprint: An Overview. Retrieved May 16, 2007 from http://www.footprintnetwork.org/gfn sub. php?content=footprint overview.

Goldman, Michael. 2001. Constructing an environmental state: Eco-governmentality and other transnational practices of a 'green' world bank. Social Problems 48(4):499-523.

Goldman, Michael, and Rachel A. Schurman. 2000. Closing the "great divide": New social theory on society and nature. Annual Review of Sociology 26:563-84.

Goonatilake, Susantha. 2006. Knowledge as an ecology. Theory, Culture \& Society 23(2-3):170-172.

Harding, Sandra. 2006. Science and Social Inequality: Feminist and Post-colonial Issues. Urbana, IL: University of Illinois Press.

Holton, Robert. 1998. Globalization and the Nation-State. New York: St. Martin's Press.

Homer-Dixon, Thomas. 2001. The Ingenuity Gap: Can we Solve the Problems of the Future? Toronto: Random House.

Intergovernmental Panel on Climate Change (IPCC). 2007. Climate Change 2007. Fourth Assessment Report of the United Nations Intergovernmental Panel on Climate Change. United Nations Environment Program and the World Meteorological Association. November.

Irwin Alan and Brian Wynne, eds. 1996. Misunderstanding Science? The Public Reconstruction of Science and Technology. Cambridge: Cambridge University Press.

Jasanoff, Sheila. 1990. The Fifth Branch: Science Advisers as Policymakers. Cambridge, MA: Harvard University Press.

Kanie, Norichika and Peter Haas, eds. 2004. Emerging Forces in Environmental Governance. New York: United Nations University Press. 
Keck, Margaret E. and Katherine Sikkink. 1998. Activists beyond Borders: Advocacy Networks in International Politics. Ithaca, NY: Cornell University Press.

Kozlarek, Oliver. 2001. Critical theory and the challenge of globalization. International Sociology 16(4):607-22.

Lewis, Tammy L. and Craig R. Humphrey. 2005. Sociology and the environment: An analysis of coverage in introductory sociology textbooks. Teaching Sociology 33(2):154-69.

Lindemann, Gesa. 2005. The analysis of the borders of the social world: A challenge for sociological theory. Journal for the Theory of Social Behaviour 35(1):70-98.

Lipschutz, Ronnie D. 1996. Global Civil Society and Global Environmental Governance: The Politics of Nature from Place to Planet. Albany, NY: State University of New York Press.

Liu, Jianguo, Thomas Dietz, Stephen R. Carpenter, Marina Alberti, Carl Folke, Emilio Moran, Alice N. Pell, Peter Deadman, Timothy Kratz, Jane Lubchenko, Elinor Ostrum, Zhiyun Ouyang, William Provencher, Charles L. Redman, Stephen H. Schneider, and William W. Taylor. 2007. Complexity of coupled human and natural systems. Science 317(14 September):1513-1516.

MacKendrick, Norah and Debra J. Davidson. 2007. State-capital relations in voluntary environmental improvement. Current Sociology 55(5):674-695.

MacKinnon, Andrew M. 2007. For an 'energetic' sociology, or, why coal, gas, and electricity should matter for sociological theory. Critical Sociology 33:345-56.

Makarenko, Jay. 2007. The Kyoto Protocol on climate change: History and highlights. Mapleleafweb, February 1. http://www.mapleleafweb.com/ features/kyoto-protocol-climate-change-history-highlights. Retrieved October 11, 2007.

Matsinhe, David M. 2007. Quest for methodological alternatives. Current Sociology 55(6):836-56.

May, Elizabeth. 2005. The environment: From local to global in a cosmic blink of 25 years. Policy Options March-April:66-71.

McDaniel, Susan. 2003. The currents of sociology internationally - Preponderance, diversity and division of labour. Current Sociology 51(6):593597.

McGregor, Sherilyn. 2006. Beyond Mothering Earth: Ecological Citizenship and the Politics of Care. Vancouver: UBC Press.

McKechnie, Rosemary B. and Ian Welsh. 2002. When the global meets the local: Critical reflections on reflexive modernization. Pp. 286-310 in Riley E. Dunlap, Frederick H. Buttel, Peter Dickens, and August Gijswijt, eds., 
Sociological Theory and the Environment: Classical Foundations, Contemporary Insights. New York: Rowman and Littlefield Publishers, Inc.

McLaughlin, Neil and Kerry Turcotte 2007. The trouble with Burawoy: An analytic, synthetic alternative. Sociology 41:813-828.

Merchant, Carolyn. 1980. The Death of Nature. New York: Harper and Row.

Migdal, Joel S. 2001. State in Society: Studying How States and Societies Transform and Constitute One Another. London: Cambridge University Press.

Millennium Ecosystem Assessment (MA). 2005. Synthesis report. Retrieved May 16, 2007 from http://www.millenniumassessment.org/en/index. $\underline{\operatorname{aspx}}$

Milton, Kay. 1996. Environmentalism and Cultural Theory. London: Routledge.

Munck, Ronaldo and Dennis O'Hearn, eds. 1999. Contributions to a New Paradigm: (Re)thinking Development in the Era of Globalization. London: Zed Books.

Murphy, Raymond. 2004. Disaster or sustainability: The dance of human agents with nature's actants. Canadian Review of Sociology and Anthropology 41(3):249-67.

Nash, Roderick F. 1989. The Rights of Nature: A History of Environmental Ethics. Madison, WI: University of Wisconsin Press.

Peet, Richard and Michael Watts, eds. 2004. Liberation Ecologies: Environment, Development, Social Movements (2nd ed.). New York: Routledge.

Plumwood, Val. 2002. Environmental Culture: The Ecological Crisis of Reason. London, New York: Routledge.

Pulido, Laura. 1998. The sacredness of "Mother Earth": Spirituality, activism, and social justice. Annals of the Association of American Geographers 88(4):719-23.

Roberts, J. Timmons and Bradley C. Parks. 2007. A Climate of Injustice: Global Inequality, North-South Politics and Climate Policy. Cambridge, MA: The MIT Press.

Robertson, Roland. 1992. Globalization: Social Theory and Global Culture. London: Sage.

1995. Glocalization: Time-space and homogeneity-heterogeneity. Pp. 25-44 in Mike Featherstone, Scott Lash, and Roland Robertson, eds., Global Modernities. London: Sage Publications.

Roth, Wolff-Michael and G.M. Bowen. 2001. Of disciplined minds and disciplined bodies: On becoming an ecologist. Qualitative Sociology 24(4): 459-81.

Sachs, Wolfgang. 1994. The blue planet: An ambiguous modern icon. The Ecologist 24(5):170-76.

Sassen, Saskia. 1998. Globalization and its Discontents. New York: New Press. 
1996. Losing Control? Sovereignty in the Age of Globalization. New York: Columbia University Press.

Saward, Michael. 1994. Democratic theory and indices of democratisation. Pp. 6-24 in David Beetham, ed., Defining and Measuring Democracy. London: Sage.

Schnaiberg, Allan 1980. The Environment: From Surplus to Scarcity. New York: Oxford University Press.

Shelley, Toby. 2005. Oil: Politics, Poverty and the Planet. London: Zed Books.

Smith, Linda Tuhiwai. 1999. Decolonizing Methodologies: Research and Indigenous Peoples. London: Zed Books.

Smith, Mick. 2001. An Ethic of Place: Radical Ecology, Postmodernity, and Social Theory. Albany, NY: State University of New York Press.

Smith, Neil. 1984. Uneven Development. Oxford: Blackwell.

Song, Samantha and Michael McGonigle. 2001. Science, power and system dynamics: The political economy of conservation biology. Conservation Biology 15(4):980-989.

Stacey, Judith. 2004. Marital suitors, court social science spin-sters: The unwittingly conservative effects of public sociology. Social Problems 51(1):131-145.

Stehr, Nico. 2001. The Fragility of Modern Societies: Knowledge and Risk in the Information Age. London: Sage Publications.

Stone, Christopher. 1974. Should Trees have Legal Standing? Toward Legal Rights for Natural Objects. Los Altos, CA: W. Kaufmann.

Sutcliffe, Robert H. 2000. Development after ecology. Pp 328-39 in J. Timmons Roberts, and Ann Hite, eds., From Modernization to Globalization: Perspectives on Development and Social Change. London: Blackwell.

Taylor, Charles. 2004. Modern Social Imaginaries. Durham, NC: Duke University Press.

Thomashow, Mitchell. 2003. Bringing the Biosphere Home: Learning to Perceive Global Environmental Change. Cambridge, MA: The MIT Press.

Urry, John. 2000. Global flows and global citizenship. Pp. 62-78 in E. Isin, ed., Democracy, Citizenship and the Global City. New York: Routledge.

Wackernagel, Mathis and William Rees. 1996. Our Ecological Footprint: Reducing Human Impact on the Earth. Gabriola Island, BC: New Society Publishers.

Watt-Cloutier, Sheila. 2004. Climate change and human rights. Human Rights Dialogue: Environmental Rights Series 2(11). Carnegie Council.

White, Damian. 2006. A political sociology of socionatures: Revisionist manoeuvres in environmental sociology. Environmental Politics 15(1):5977. 
Randolph Haluza-DeLay is an Assistant Professor of sociology at The King's University College, and Debra Davidson is an Associate Professor of sociology at the University of Alberta, both in Edmonton. Davidson is editor (with Kierstan Hatt) of Consuming Sustainability (Fernwood). Haluza-DeLay is one of the editors of the forthcoming Speak for Ourselves: Environmental Justice in Canada (University of British Columbia Press, 2009). 